\title{
ENDOTOXIN EXPOSURE ASSESSMENT IN WOOD-PROCESSING INDUSTRY: AIRBORNE VERSUS SETTLED DUST LEVELS
}

\author{
Ivana SABOLIĆ PIPINIĆ ${ }^{1}$, Veda Marija VARNAI ${ }^{1}$, Ružica BELJO LUČIĆ ${ }^{2}$ \\ Ankica ČAVLOVIĆ ${ }^{2}$, Ljerka PRESTER ${ }^{1}$, Tatjana ORCT ${ }^{1}$, and Jelena MACAN ${ }^{1}$ \\ Institute for Medical Research and Occupational Health ${ }^{1}$, Faculty of Forestry, University of Zagreb ${ }^{2}$, Zagreb, Croatia
}

Received in August 2009

Accepted in January 2010

\begin{abstract}
Wood processing is usually performed in environments with large amounts of endotoxin-rich bioaerosols that are associated with a variety of health effects. The aim of this preliminary study was to assess the relation between endotoxin levels in settled and airborne dust in wood-processing industry. Ten pairs of airborne and settled dust samples were collected in a sawmill and parquet manufacture of two wood-processing plants in Croatia. Endotoxin was assayed with a chromogenic end-point LAL (Limulus amebocyte lysate) method. The results showed that endotoxin levels in airborne respirable dust were above the proposed occupational exposure limit of $125 \mathrm{EU} \mathrm{m}^{-3}$ and could be considered hazardous for the respiratory system. In settled dust they ranged between $229.7 \mathrm{EU} \mathrm{mg}^{-1}$ and $604.3 \mathrm{EU} \mathrm{mg}^{-1}$ and in airborne dust between $166.8 \mathrm{EU} \mathrm{mg}^{-1}$ and $671.6 \mathrm{EU} \mathrm{m}^{-3}$, but there was no significant correlation between them (Spearman's $\mathrm{rho}=0.358, \mathrm{P}=0.310$ ). This study points to sawmill settled dust as endotoxin reservoir and suggests that it may add to already high exposure to airborne endotoxins associated with wood processing. Investigations of the relation between settled and airborne endotoxin levels should be continued to better understand the sources and sites of endotoxin contamination in wood-processing industry.
\end{abstract}

KEY WORDS: airborne dust, bioaerosols, LAL test, parquet manufacture, sawmill

Endotoxins are integral components of the outer membrane of Gram-negative bacteria with strong inflammatory properties (1). Released in the environment, they make an important, biologically active component of organic dust at home and work, and, if inhaled, induce dose-related inflammatory response (2). Occupational monitoring of endotoxin is mostly based on airborne endotoxin levels $(1,3)$, while measurement in settled dust is not as common in occupational settings, even though it is less expensive and less time consuming. There are indications, however, that settled dust endotoxin could be used as an indicator of indoor endotoxin exposure $(4,5)$.

The aim of this preliminary study was to compare settled and airborne dust endotoxin levels in wood- processing industry measured at the same time, since such data are not available in published literature. Wood-processing industry is one of the working environments with large amounts of endotoxin-rich bioaerosols, which are associated with various health effects $(1,3)$.

\section{METHODS}

\section{Sampling}

Air dust and settled dust were sampled at two Croatian sawmills (A and B) and the parquet manufacture unit of sawmill B over the summer. Sawmill A processed solid beechwood (Fagus 
silvatica L.), oakwood (Quercus Robur L.), and firwood (Abies Alba Mill.), and sawmill B, processed ashwood (Fraxinus angustifolia Vahl.) in addition to beechwood and oakwood. Samples were gathered during sawing and debarking of logs in both sawmills and during parquet manufacture in sawmill B. Five pairs of air dust and settled dust samples were collected in Sawmill A, three pairs in sawmill B, and two pairs in the parquet manufacture unit of sawmill B.

Airborne dust samples were collected with stationary samplers for respirable particles (Casella, Bedford, UK). The device was attached to a stand near the workplace or working machine, with the collecting positioned in the breathing area according to the HRN CEN/TR 15230:2005 standard (6). Sampler cellular filters (Whatman International Ltd., Maidstone, UK) were stored at $-20^{\circ} \mathrm{C}$ until extraction. Control filters were handled, stored, and analysed for endotoxin load in the same way as the sample filters.

Settled dust samples were taken from a floor area of a square metre or two in close vicinity of a corresponding air dust sampler. Each sample was collected with a brush in a clean plastic bag and stored at $-20{ }^{\circ} \mathrm{C}$ until extraction. At each sampling site, air temperature, relative humidity, and airflow velocity were measured using a Kestrel ${ }^{\circledR} 4000$ Pocket Weather ${ }^{\mathrm{TM}}$ Tracker $^{\mathrm{TM}}$ (Nielsen-Kellerman Co., USA).

\section{Endotoxin measurement}

Each filter was placed in $5 \mathrm{~mL}$ of pyrogen-free LAL water (Endosafe, lot no. 997320659) containing $0.05 \%$ Tween-20 (LAL-T). Dust samples were sieved and $100 \mathrm{mg}$ of fine dust was extracted in $10 \mathrm{~mL}$ of pyrogen-free LAL-T. The extracts were centrifuged and supernatants transferred into pyrogen-free glassware at $75{ }^{\circ} \mathrm{C}$ for $20 \mathrm{~min}$ to avoid any possible interference (7).

Endotoxins were analysed on the day of extraction using a quantitative chromogenic end-point LAL method (Limulus amebocyte lysate) at $37^{\circ} \mathrm{C}$. Glassware was rendered pyrogen-free by heating it to $180^{\circ} \mathrm{C}$ for $4 \mathrm{~h}$. A commercial kit for endotoxin analysis was purchased from Charles River Endosafe (Charleston, USA; lot no. Y4042CT1 and lot no.V2242CTK1). For standard, we used the Escherichia coli endotoxin (Endosafe; CSE lot no. ET 84092) with a potency of $4 \mathrm{EU} \mathrm{ng}^{-1}$. Aliquots $(100 \mu \mathrm{L})$ of reference standard, extracts, reagent blanks, and controls were added to pyrogen-free microtitre plates (Greiner Labortechnik, $\mathrm{GmbH}$, Germany), and assayed in duplicate as described earlier (8). Standards were prepared as twofold dilutions containing endotoxin concentrations from $0.015 \mathrm{EU} \mathrm{mL}^{-1}$ to $1.2 \mathrm{EU} \mathrm{mL}^{-1}$. Optical density was read at $405 \mathrm{~nm}$ on a Personal Lab 96-well microplate reader (Iason, Graz, Austria). Endotoxin concentrations are expressed as endotoxin units (EU) per milligram of dust $\left(\mathrm{EU} \mathrm{mg}^{-1}\right)$ or per cubic meter of sampled air $\left(\mathrm{EU} \mathrm{m}^{-3}\right)$. The maximum sensitivity of the test was $0.015 \mathrm{EU} \mathrm{mL}^{-1}$.

\section{Statistical analysis}

Nonparametric statistics was applied, because endotoxin data were not normally distributed. Descriptive statistics, testing of the difference in endotoxin values between the two sawmills (MannWhitney U test), and testing of the correlation between airborne and settled dust endotoxin values (Spearman correlation) were performed using statistical software Stata/SE 10.0 for Windows (StatCorp LP, TX, USA).

\section{RESULTS}

Measurements in both sawmills were performed during the summer with temperatures at sampling sites ranging from $24.4{ }^{\circ} \mathrm{C}$ to $30^{\circ} \mathrm{C}$ (median $27.8^{\circ} \mathrm{C}$ ). Relative humidity ranged from $47 \%$ to $56.3 \%$ (median $51.2 \%$ ). Airflow velocity was $0 \mathrm{~m} \mathrm{~s}^{-1}$ at both sawmills.

Table 1 shows endotoxin values in parallel samples of airborne and settled dust. No differences were found between the two sawmills, either for airborne dust [sawmill A: median 261.7 $\mathrm{EU} \mathrm{m}^{-3}$, range: (228.1 to 617.6) $\mathrm{EU} \mathrm{m}^{-3}$; sawmill B: median $280.5 \mathrm{EU} \mathrm{m}^{-3}$, rang: (166.8 to 671.6) $\left.\mathrm{EU} \mathrm{m}^{-3} ; \mathrm{z}=0.313, \mathrm{P}=0.754\right]$ or for settled dust [sawmill A: median $474.3 \mathrm{EU} \mathrm{mg}^{-1}$, range: (255.2 to 500.9) $\mathrm{EU} \mathrm{mg}^{-1}$; sawmill $\mathrm{B}$ : median 330.6 EU mg ${ }^{-1}$, range: (229.7 to 604.3) $\mathrm{EU} \mathrm{mg}^{-1} ; \mathrm{z}=$ $-0.104, \mathrm{P}=0.917]$. The same is true for the two samples collected from parquet manufacture, and this is why we pooled data from both sawmills, including parquet manufacture, for further analysis. Endotoxin in settled and in airborne dust was relatively limited in range [(229.7 to 604.3) $\mathrm{EU} \mathrm{mg}^{-1}$ and (166.8 to 671.6) $\mathrm{EU} \mathrm{m}^{-3}$, respectively)] and there was no significant correlation between the two (Spearman's rho $=0.358, \mathrm{P}=0.310$ ).

\section{DISCUSSION AND CONCLUSIONS}

In this study, all endotoxin levels in airborne dust were above the exposure limit of $5 \mathrm{ng} \mathrm{m}^{-3}$ ( $50 \mathrm{EU}$ 
Table 1 Endotoxin levels in settled and airborne dust from sawmills

\begin{tabular}{|c|c|c|c|}
\hline Sample pair & Type of operation & $\begin{array}{l}\text { Airborne endotoxin / } \\
\text { EU m } \\
\end{array}$ & $\begin{array}{c}\text { Settled dust endotoxin / } \\
\text { EU mg }\end{array}$ \\
\hline 1 & sawmill $\mathrm{A}^{\mathrm{a}}$ & 232.1 & 255.2 \\
\hline 2 & sawmill $\mathrm{A}^{\mathrm{a}}$ & 228.1 & 292.3 \\
\hline 3 & sawmill $\mathrm{A}^{\mathrm{a}}$ & 261.7 & 474.3 \\
\hline 4 & sawmill $\mathrm{A}^{\mathrm{a}}$ & 316.6 & 494.9 \\
\hline 5 & sawmill $\mathrm{A}^{\mathrm{a}}$ & 617.6 & 500.9 \\
\hline 6 & sawmill Ba & 232.6 & 558.2 \\
\hline 7 & sawmill Ba & 166.8 & 229.7 \\
\hline 8 & sawmill $\mathrm{B}^{\mathrm{a}}$ & 671.6 & 260.2 \\
\hline 9 & $\begin{array}{l}\text { parquet manufacturing } \\
\text { unit }^{\mathrm{b}} \text { (sawmill B) }\end{array}$ & 357.1 & 330.6 \\
\hline 10 & $\begin{array}{l}\text { parquet manufacturing } \\
\text { unit (sawmill B) }\end{array}$ & 280.5 & 604.3 \\
\hline \multicolumn{4}{|c|}{ All samples (sawmills and parquet) } \\
\hline \multicolumn{2}{|c|}{ Median (interquartile range) } & $271.1(232.1$ to 357.1$)$ & 402.5 (260.2 to 500.9$)$ \\
\hline \multicolumn{2}{|c|}{ Arithmetic mean $\pm \mathrm{SD}$} & $336.5 \pm 171.0$ & $400.1 \pm 140.4$ \\
\hline
\end{tabular}

${ }^{a}$ Wet-wood processing

${ }^{b}$ Dry-wood processing

Table 2 Comparison of airborne and settled dust endotoxin levels in different environments

\begin{tabular}{|c|c|c|c|c|c|c|}
\hline \multirow{2}{*}{$\begin{array}{l}\text { Environment } \\
\text { (number of settled dust } \\
\text { samples / number of } \\
\text { airborne dust samples) }\end{array}$} & \multicolumn{2}{|c|}{$\begin{array}{c}\text { Settled endotoxin / } \\
\text { EU mg }\end{array}$} & \multicolumn{2}{|c|}{$\begin{array}{c}\text { Airborne endotoxin / } \\
\mathrm{EU} \mathrm{m}^{-3}\end{array}$} & \multirow{2}{*}{$\begin{array}{c}\text { Ratio of settled } \\
\text { and airborne dust } \\
\text { endotoxin average } \\
\text { values }\end{array}$} & \multirow{2}{*}{ Reference } \\
\hline & Average & Range & Average & Range & & \\
\hline Household $(93 / 116)^{c}$ & $96^{\mathrm{a}}$ & 28 to 1945 & $0.77^{\mathrm{a}}$ & 0.01 to 30.23 & 125 & 21 \\
\hline Household $(24 / 23)^{d}$ & $8.7^{\mathrm{a}}$ & 21 to 48.0 & $0.43^{\mathrm{a}}$ & 0.05 to 3.99 & 20 & 4 \\
\hline Aircraft cabin $(32 / 28)^{c}$ & $120^{\mathrm{a}}$ & 3.8 to 420 & $1.5^{\mathrm{a}}$ & 0.53 to 5.3 & 80 & 20 \\
\hline \multicolumn{7}{|l|}{ Animal houses ${ }^{\mathrm{e}}$} \\
\hline Dairy cattle (11/22) & $365^{b}$ & 51 to 1032 & $3.1^{\mathrm{b}}$ & 0.3 to 61 & 118 & \multirow{5}{*}{5} \\
\hline Beef cattle $(3 / 6)$ & $1079^{b}$ & 95 to 1114 & $10.2^{b}$ & 0.9 to 31 & 106 & \\
\hline Pigs (9/18) & $778^{\mathrm{b}}$ & 147 to 2288 & $23.1^{\mathrm{b}}$ & 1.9 to 236 & 34 & \\
\hline Laying hens (8/18) & $754^{b}$ & 137 to 11169 & $62^{\mathrm{b}}$ & 2.5 to 12282 & 12 & \\
\hline Turkeys (3/6) & $2100^{b}$ & 502 to 4408 & $362^{b}$ & 94 to 762 & 6 & \\
\hline Sawmills $(10 / 10)$ & $402.5^{b}$ & 229.7 to 604.3 & $271.1^{\mathrm{b}}$ & 166.8 to 671.6 & 1.5 & $\begin{array}{c}\text { Present } \\
\text { study }\end{array}$ \\
\hline
\end{tabular}

$a$ - geometric mean; $b$ - median; $c$ - endotoxin analysed in total dust; $d$ - endotoxin analysed in inhalable dust; $e$ - endotoxin analysed in respirable dust

$\mathrm{m}^{-3}$ ) proposed by The National Health Council of the Netherlands (DECOS) (9) and above the occupational exposure limit of $12.5 \mathrm{ng} \mathrm{m}^{-3}\left(125 \mathrm{EU} \mathrm{m}^{-3}\right)$ set by the International Commission on Occupational Health (ICOH) (10). As Rylander and Carvalheiro have proposed $10 \mathrm{ng} \mathrm{m}^{-3}\left(100 \mathrm{EU} \mathrm{m}^{-3}\right)$ as the threshold for airway inflammation (11), endotoxin levels in our study may be hazardous for the respiratory system.

A wide range of endotoxin levels in airborne dust in woodworking industry has been described in literature, mainly for inhalable and total dust.
They vary with occupational settings and climate, including the type of woodworking process (e.g. wet $v s$ dry wood processing), dust levels, and atmospheric conditions (temperature, air humidity and flow). The influence of sampling methods, transport conditions, and methods of extraction and analysis must also be taken into account (12). Most of these studies found endotoxin levels to exceed exposure limits (13-17) and were similar to our results for endotoxin in airborne dust in similar sampling conditions (wet wood processing over the summer). Low endotoxin levels 
$\left(<50 \mathrm{EU} \mathrm{m}^{-3}\right)$ were found only in Swiss (18) and Swedish (19) sawmills. All of these studies assessed exposure only to airborne dust endotoxin. Our study has ventured further with measurements of settled dust endotoxin in order to see the relation between airborne and settled dust endotoxin levels. Similar comparisons have been made before in various settings, but not in woodworking industry (Table 2). They suggest that settled dust can be an indoor reservoir of endotoxins, and therefore a health hazard, should it be raised by indoor activities $(20,21)$. Our study showed a similar endotoxin load in airborne and settled dust but no significant correlation between the two. The ratio between median endotoxin levels in settled and airborne (respirable) dust was only 1.5. Similar low ratios were found in poultry houses for turkeys and laying hens ( 6 and 12 , respectively), where settled dust is expected to be highly disturbed (5). In contrast, this ratio in households, aircraft cabins, and cattle stables is usually between 80 and 125 , suggesting only minor disturbance of floor endotoxin reservoirs $(5,21,22)$.

To conclude, this study has pointed to sawmill settled dust as a relevant endotoxin reservoir and has suggested that it may add to already high exposure to airborne endotoxins associated with wood processing. Our initial results of endotoxin exposure in Croatian sawmills suggest that the relation between settled and airborne dust endotoxin levels need to be further investigated to better understand the sources and sites of endotoxin contamination in sawmills, and the risk posed by endotoxin reservoirs in settled dust to human health in particular. This knowledge could change the way we assess endotoxin exposure and could have practical implications on safety at work and health protection in wood-processing industry and other environments.

\section{Acknowledgement}

This study was supported by the grant number 022 0222411-2410 financed by the Ministry of Science, Education and Sports of the Republic of Croatia.

\section{REFERENCES}

1. Rylander R. Endotoxin in the environment-exposure and effects. J Endotoxin Res 2002;8:241-52.

2. Liebers V, Raulf-Heimsoth M, Brüning T. Health effects due to endotoxin inhalation. Arch Toxicol 2008;82:203-10

3. Douwes J, Thorne P, Pearce N, Heederik D. Bioaerosol health effects and exposure assessment: progress and prospects. Ann Occup Hyg 2003;47:187-200.
4. Hyvärinen A, Roponen M, Tiittanen P, Laitinen S, Nevalainen A, Pekkanen J. Dust sampling methods for endotoxin - an essential, but underestimated issue. Indoor Air 2006;16:207.

5. Schierl R, Heise A, Egger U, Schneider F, Eichelser R, Neser S, Nowak D. Endotoxin concentration in modern animal houses in southern Bavaria. Ann Agric Environ Med 2007;14:129-36.

6. Workplace atmospheres - Guidance for sampling in inhalable, thoracic and respirable aerosol fractions (CEN/TR 15230:2005)

7. US Food and Drug Administration (FDA). Guideline on validation of the Limulus amebocyte lysate test as an end-product endotoxin test for human and animal parenteral drugs, biological products and medical devices 1987 [displayed 29 March 2010]. Available at http:// www.fda.gov/downloads/BiologicsBloodVaccines/ GuidanceComplianceRegulatoryInformation/Guidances/ Blood/UCM080966.pdf.

8. Varnai VM, Macan J, Plavec D, Jureša D. Endotoxin measurement in house dust using the end-point Limulus amoebocyte lysate method. Arh Hig Rada Toksikol 2004;55:175-81.

9. Dutch Expert Committee on Occupational Standards (DECOS). Health-based recommended occupational exposure limit for endotoxins. Publication no. 1998/03WGD. Rijswijk: Health Council of the Netherlands; 1998.

10. Radon K, Danuser B, Iversen M, Monso E, Weber C, Hartung J, Donham K, Palmgren U, Nowak D. Air contaminants in different European farming environments. Ann Agric Environ Med 2002;9:41-8.

11. Rylander R, Carvalheiro MF. Airways inflammation among workers in poultry houses. Int Arch Occup Environ Health 2006;79:487-90.

12. Spaan S, Heederik DJ, Thorne PS, Wouters IM. Optimization of airborne endotoxin exposure assessment: effects of filter type, transport conditions, extraction solutions, and storage of samples and extracts. Appl Environ Microbiol 2007;73:613443.

13. Mandryk J, Alwis KU, Hocking AD. Effects of personal exposures on pulmonary function and work-related symptoms among sawmill workers. Ann Occup Hyg 2000;44:281-9.

14. Rongo LM, Msamanga GI, Burstyn I, Barten F, Dolmans WM, Heederik D. Exposure to wood dust and endotoxin in small-scale wood industries in Tanzania. J Expo Anal Environ Epidemiol 2004;14:544-50.

15. Duchaine C, Thorne PS, Mériaux A, Grimard Y, Whitten P, Cormier Y. Comparison of endotoxin exposure assessment by bioaerosol impinger and filter-sampling methods. Appl Environ Microbiol 2001;67:2775-80.

16. Douwes J, McLean D, van der Maarl E, Heederik D, Pearce N. Worker exposures to airborne dust, endotoxin and beta(1,3)-glucan in two New Zealand sawmills. Am J Ind Med 2000;38:426-30.

17. Dennekamp M, Demers P, Bartlett K, Davies H, Teschke K. Endotoxin exposure among softwood lumber mill workers in the Canadian province of British Columbia. Ann Agric Environ Med 1999;6:141-6.

18. Oppliger A, Rusca S, Charrière N, Vu Duc T, Droz PO. Assessment of bioaerosols and inhalable dust exposure in Swiss sawmills. Ann Occup Hyg 2005;49:385-91. 
19. Dahlqvist M, Johard U, Alexandersson R, Bergström B, Ekholm U, Eklund A, Milosevich B, Tornling G, Ulfvarson U. Lung function and precipitating antibodies in low exposed wood trimmers in Sweden. Am J Ind Med 1992;21:549-59.

20. Bouillard L, Michel O, Dramaix M, Devleeschouwer M. Bacterial contamination of indoor air, surfaces, and settled dust, and related dust endotoxin concentrations in healthy office buildings. Ann Agric Environ Med 2005;12:187-92.
21. Hines CJ, Waters MA, Larsson L, Petersen MR, Saraf A, Milton DK. Characterization of endotoxin and 3-hydroxy fatty acid levels in air and settled dust from commercial aircraft cabins. Indoor Air 2003;13:166-73.

22. Park JH, Spiegelman DL, Gold DR, Burge HA, Milton DK. Predictors of airborne endotoxin in the home. Environ Health Perspect 2001;109:859-64. 


\section{Sažetak \\ IZLOŽENOST ENDOTOKSINU U DRVOPRERAĐIVAČKOJ INDUSTRIJI: ODNOS IZMEĐU RAZINA IZMJERENIH U ZRAKU I NA TLU}

Drvoprerađivačka industrija radna je sredina s izloženošću velikim količinama bioaerosola bogatog endotoksinom, što je povezano s učincima na zdravlje izložene radne populacije. Cilj ove studije bio je procijeniti odnos između razina endotoksina u sedimentiranoj prašini i zraku (aerosoliziranoj prašini) drvoprerađivačkih radnih prostora. Deset parova uzoraka zraka i sedimentirane prašine skupljeno je u dvije tvornice za preradu drva (pilanama i pogonima za proizvodnju parketa) u Hrvatskoj. Endotoksin je izmjeren kromogenom "end-point" LAL (Limulus amebocitni lizat) metodom. Rezultati su pokazali da razine endotoksina u aerosoliziranoj respirabilnoj prašini drvoprerađivačkih pogona prelaze preporučene granice izloženosti za radne prostore od $125 \mathrm{EU} \mathrm{m}^{-3}$, pa se mogu smatrati štetnima za dišni sustav izloženih radnika. Razine endotoksina izmjerene u sedimentiranoj i aerosoliziranoj prašini kretale su se u sličnu rasponu [(229.7 do 604.3) $\mathrm{EU} \mathrm{mg}^{-1} \mathrm{i}$ (166.8 do 671.6) $\mathrm{EU} \mathrm{m}^{-3}$ ], ali nije utvrđena značajna korelacija razina endotoksina između parova uzoraka sedimentirane $\mathrm{i}$ aerosolizirane prašine (Spearman rho $=0.358, \mathrm{P}=0.310$ ). Ovi rezultati upućuju na to da uz velike količine proizvedene i aerosolizirane drvne prašine u sklopu radnih operacija u pilanama, razini endotoksina u aerosoliziranoj respirabilnoj prašini može pridonijeti i uskovitlana sedimentirana prašina koja je dodatni rezervoar endotoksina. Istraživanje odnosa između razina endotoksina u sedimentiranoj i aerosoliziranoj prašini treba nastaviti kako bi se bolje definirali izvori i mjesta kontaminirana endotoksinom u pilanama.

KLJUČNE RIJEČI: aerosolizirana prašina, bioaerosoli, LAL-test, proizvodnja parketa, pilana, sedimentirana prašina

\section{CORRESPONDING AUTHOR:}

Jelena Macan, MD, PhD

Occupational Health and Environmental Medicine Unit Institute for Medical Research and Occupational Health Ksaverska cesta 2, 10000 Zagreb, Croatia

E-mail:jmacan@imi.hr 